INDEPENDENT JOURNAL OF MANAGEMENT \& PRODUCTION (IJM\&P)

http://www.ijmp.jor.br

v. 12, n. 4, May-June 2021

ISSN: 2236-269X

DOI: 10.14807/ijmp.v12i4.1309

\title{
DIFFERENCES AND SIMILARITIES IN THE MILK PRODUCTION CHAIN: A COMPARATIVE ANALYSIS WITH THE STATES OF MINAS GERAIS AND PARANÁ
}

\author{
Adriano Oliveira Cruz \\ Universidade Federal de Lavras, Brazil \\ E-mail: adrianocruz.zoo@gmail.com \\ José Kennedy Lopes Silva \\ Universidade Federal de Lavras, Brazil \\ E-mail: kennedysilv@gmail.com \\ Elvis Magno da Silva \\ Universidade Federal de Lavras, Brazil \\ E-mail: elvismagnosilva@gmail.com \\ Antônio Carlos dos Santos \\ Universidade Federal de Lavras, Brazil \\ E-mail: acsantos@ufla.br \\ Luiz Marcelo Antonialli \\ Universidade Federal de Lavras, Brazil \\ E-mail: Imantonialli@ufla.br \\ Submission: 3/12/2020 \\ Revision: 5/13/2020 \\ Accept: 8/12/2020
}

\section{ABSTRACT}

Brazilian agriculture has played a prominent role all over the world, being milk production one of the exponents of the national agribusiness. The states of Minas Gerais and Paraná are protagonists in the milk production business in the country. The objective of this study was to evaluate the differences and similarities of the milk production chain in these two states, considering the period from 2008 to 2017, in order to investigate their dynamics and their competitiveness. The methodological approach adopted in the research was of a quantitative nature, with the use of the software "Statistical Package for the Social Sciences” (SPSS), which allowed the analysis to be carried out with the statistical techniques of analysis of variance (Anova) and cluster analysis. Ward's agglomerative method and discriminant analysis were also adopted. The state of Minas Gerais presented a superior milk production chain in comparison with Paraná in every year analyzed; 
DOI: 10.14807/ijmp.v12i4.1309

however, statistically there was no significant difference in the milk production from 2009 to 2017. Paraná presented better milk productivity averages as compared to Minas Gerais; it was highly significant (1\%) from 2008 to 2016 and significant (5\%) in 2017. The results of the cluster analysis indicated that, due to the fact that Paraná has higher productivity indexes in relation to Minas Gerais, its limits are better in relation to Minas Gerais in the analyzed aspects. It was found that some municipalities that are considered to have high productivity in Minas Gerais do not enter this same group in Paraná. It can be said that Paraná was shown to be more efficient in the milk production chain as compared to Minas Gerais in the analyzed time period. The article indicates the need to improve the technology used in the milk production chain, so that the numbers related to productivity can be improved. In addition, it was found that it is necessary to invest in genetics and technical assistance so that milk producers in the states surveyed can become more competitive.

Keywords: Productive chain. Milk. Minas Gerais. Paraná. Brazil

\section{INTRODUCTION}

With the population increase and its consequent demand for food, Brazil will be one of the major global players in the supply of agribusiness produce (Bacha, 2000). According to the Food and Agriculture Organization (FAO), an estimated 70\% increase in total demand for food is expected by 2050 (Fao, 2009). In 2015, this same entity pointed out that around 805 million people in the world did not have enough food to lead a healthy and active life.

Agribusiness is the main economic segment responsible for generating employment, income and food in Brazil (Assman et al., 2016). The country is one of the world leaders in the production and export of various agricultural produce. The country is the first producer and exporter of coffee, sugar, alcohol and fruit juices. Additionally, it leads the ranking of foreign sales of soybeans, beef, chicken, tobacco, leather and leather shoes.

In a study that analyzes the period from 2001 to 2010, the authors state that agribusiness corresponded to 38\% of all Brazilian international business (Leme, 2011). This number is significant, given that it is a single segment that holds more than a third of all international transactions in the country. Even in 2008 and 2009, a period in which there was an abrupt reduction in the comparison between one year and another regarding total exports (22.7\% decrease), agribusiness had a considerable less significant decrease of less than $10 \%$ (Leme, 2011). 
DOI: 10.14807/ijmp.v12i4.1309

An analysis of the Brazilian national market highlights the growth of the product "milk”, with dairy farming standing out in Brazilian agribusiness. It is responsible for an important part of the investments made in the country, represented by producers, industries, commerce, government and consumers. States such as Minas Gerais, Paraná, Rio Grande do Sul, Goiás, Rondônia, São Paulo and others stand out in the milk production chain. In this study, we focus on the states of Minas Gerais and Paraná, which are important milk producers in the country. The objective of this study was to evaluate the differences and similarities of the milk production chains in Minas Gerais and Paraná in the years from 2008 to 2017, aiming at understanding the dynamics and competitiveness relationships that exist in the structures of each milk production chain.

This work is structured in four sections. After this introduction, the second section deals with the specific approach of the milk production system in Brazil. After that, it will be presented how the milk production chains in Minas Gerais and in Paraná work. The economic data of the two states surveyed will be presented in the last section and a statistical analysis will be then carried out.

\section{LITERATURE REVIEW}

\subsection{Milk Agribusiness In Brazil}

The context of dairy production in Brazil is diverse and heterogeneous. There is milk production in all regions and states of the country, and some regions and states stand out in relation to the others - the South and Southeast regions and the states of Paraná and Minas Gerais are examples of that (Lopes Júnior et al., 2012). Another important factor is that there is no specific pattern of production in Brazil and such process makes it difficult to have a greater production when it comes to comparing it with the production of other countries (Lopes Júnior et al., 2012).

Dairy farming has remained on the sidelines in Brazilian agriculture for more than three centuries. Since the end of the $19^{\text {th }}$ century, dairy farming has increased its production in Brazilian farms. This occurred largely due to the coffee decline and the modernization of farms (Vilela et al., 2017). Regarding such modernization, it is important to point out that it was only from the 1950s onwards that the technology of farms expanded, mainly due to the country's second industrial revolution. 
INDEPENDENT JOURNAL OF MANAGEMENT \& PRODUCTION (IJM\&P)

http://www.ijmp.jor.br

v. 12, n. 4, May-June 2021

ISSN: 2236-269X

DOI: 10.14807/ijmp.v12i4.1309

Frame 1: Historical overview of dairy farming in Brazil

\begin{tabular}{|c|l|}
\hline Features & \multicolumn{1}{c|}{ Chronology } \\
\hline Origin of livestock & $\begin{array}{l}16 \mathrm{t}^{\mathrm{h}} \text { century: first cattle arrived in the country; dairy farming did not exist until } \\
1950 ; \text { after this year, husbandry was driven by technological modernization. }\end{array}$ \\
\hline Modernization & $\begin{array}{l}\text { Since 1950: public policies implemented by the Government have driven the } \\
\text { regularization of milk quality and production in the country. }\end{array}$ \\
\hline Impact on livestock & $\begin{array}{l}\text { Since 1990: The maturation of the milk production chain has led to significant } \\
\text { growth and resulted in domestic production, due to the growth of the herd, } \\
\text { substantial imports and, above all, increased productivity. }\end{array}$ \\
\hline
\end{tabular}

In Brazil, in the last 50 years, milk production has grown considerably, despite government interventions such as economic plans, prices and controlled imports. Milk production in Brazil has shown growth since the first records released in 1961 by FAO. From the 1990s onwards, the milk production chain was transformed in the context of a crisis involving the lack of specialization of rural producers. It was necessary to make several advancements from the end of the 1990s and from the beginning of the 2000s that ended up modifying the behavior of the agents of the milk production chain. Such transformations were possible due to the proximity of producers with universities and research centers (Slomp, 2003).

There are also some improvements to be considered in the political and economic field which reflected in the other links of the milk production chain. The roles of the Organização das Cooperativas Brasileiras (OCB), of the Leite Brasil and of the Confederação da Agricultura Nacional de Pecuária do Leite (CNPL) (respectively, Organization of Brazilian Cooperatives, Brazilian Milk and Confederation of the National Agriculture for Livestock of Milk) stand out. The main advances that public and private policies have offered the milk production chain in Brazil are related to trade defense. Regarding the imports of milk produce in Brazil, some important measures can be mentioned: a) the prohibition of the production and marketing of long-life milk; b) the adoption of the prior consent of the Ministry of Agriculture to verify the quality of the milk to be imported; c) the raising of taxes for the import of dried milk and of cheeses in order to protect Brazilian producers (Slomp, 2003).

The specialization of dairy farming is, in fact, an important aspect that has been improved in dairy production in Brazil. Resources allocated by the Ministry of Agriculture via rural credit contributed significantly to the specialization of dairy farming (Slomp, 2003). Modernization is also a major factor in the growth of dairy farming in Brazil (Vilela et al., 2017). Dairy production has already experimented considerable influences from technology to increase its production. It is estimated that, in order to be even more productive, more 
DOI: 10.14807/ijmp.v12i4.1309

technological investments on behalf of the government, of dairy producers and of the entire milk production chain will be necessary.

Dairy farming is an important segment of the country's rural economy, as it generates jobs within a very dynamic chain that involves several actors (Perobelli, Araújo Júnior \& Castro, 2018). Brazilian milk production leveraged mainly due to the creation of public policies, which offered support, stimulated milk production and also showed the most productive regions of Brazil in that respect, which are Southeast, South and Midwest regions (Moraes \& Bender Filho, 2017). The North and Northeast regions have lower numbers even with a significant herd.

The "productive chain”, concept discussed by (Brum, Kelm \& Albornoz, 2014), is considered in this work as a set of activities and practices that are articulated in order to accomplish a certain objective, mainly economic, according to several authors (Zylbersztain, 2000; Proechnik \& Haguenauer, 2002; Batalha, 2007; Brum, 2012). The production chains are the result of interdependent movements among actors that subsidize structure, equipment and consumer products and mediate the entire production process until the final result of distribution and commercialization of a product.

Figure 1 summarizes the configuration of the milk production chain in Brazil (Perobelli, Araújo Júnior \& Castro, 2018).

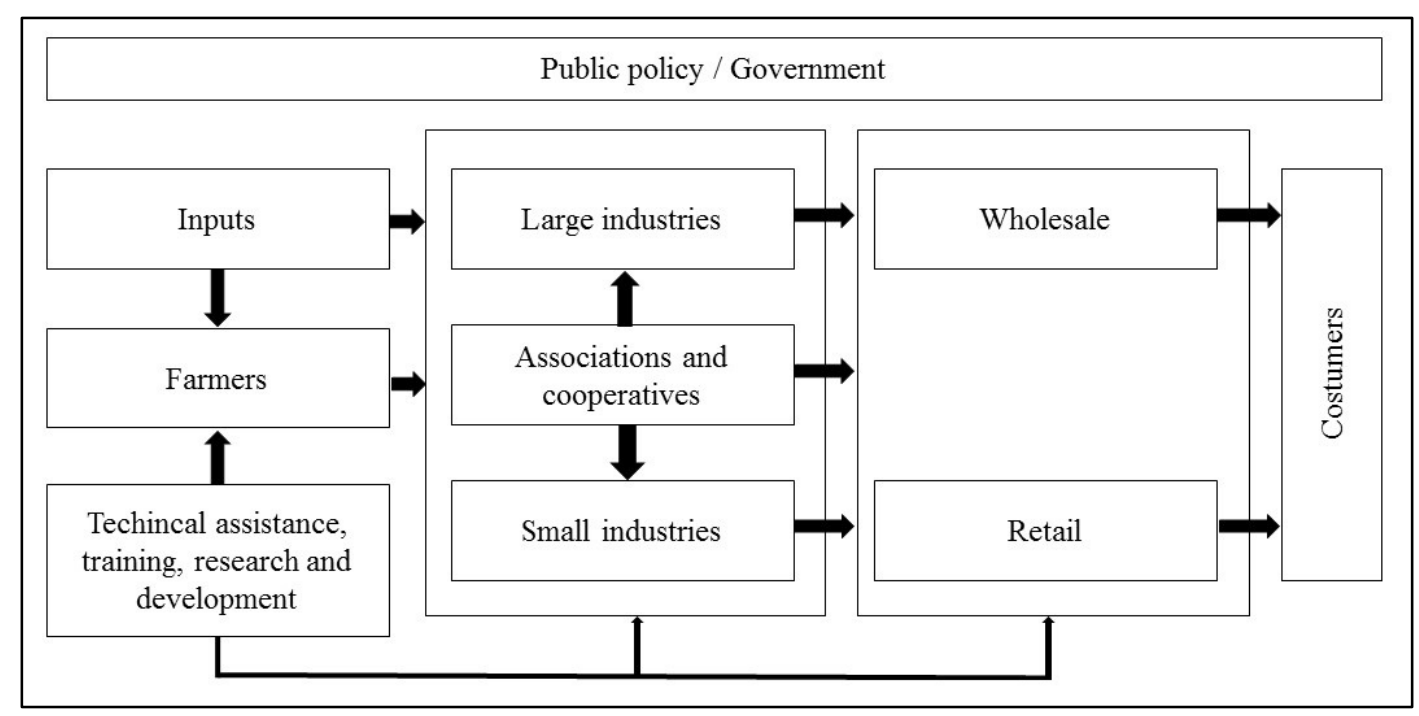

Figure 1: Milk production chain

Source: Available in (Perobelli, Araújo Júnior \& Castro, 2018, p. 301).

The first horizontal axis represents the public sector and its responsibilities towards the dairy activity. Its main function is to support dairy farmers in their production. Consequently, it involves the beginning of the network composed of the private actors that surround the chain and it has as its responsibility to make the milk production infrastructure available to other 
DOI: 10.14807/ijmp.v12i4.1309

players in this process. The second axis, in the vertical direction, plays the role of distributing fresh production to large industries, associations and cooperatives and small industries that are responsible for processing the product for later delivery to wholesalers and retailers, who consequently give the customers access to the produced and packaged milk.

The milk production chain is formed by several agents that interact among each other from the moment of the production of inputs, first link in the chain, which connects manufacturers, equipment, credit and educational and research organizations. In the second link, we find the producers who raise the animals and produce the milk. After that, there are industries that transform the raw material and are also responsible for the transportation and distribution of the milk. Finally, we have the consumers who buy the dairy products (Brum, Kelm \& Albornoz, 2014). This whole production chain needs good governance execution by the mentioned actors, so that the product has a good standard in production and marketing to reach consumers with quality. The involvement of all actors in the chain is important for the dairy industry to continue standing out in the national economy.

In Brazil, the numbers of individual milk producers have been decreasing in recent decades. However, this decrease has not affected milk production, a fact which can be justified by the technological evolution and professionalization of milk production in the country (Vilela et al., 2017). The consumption of such drink has also been growing and this is due to several factors, such as population and economic growth, shifts in consumer eating habits, greater milk production and consumer access to the product.

Brazilian dairy farming was encouraged to produce derivatives. This, however, generated a prospect of importing milk from neighboring countries in South America, namely Argentina, Uruguay and Chile (Moraes \& Bender Filho, 2017). The export market in Brazil is still in development, but it is promising. It needs actions and policies so that the commercialization of Brazilian milk outside the country can be consolidated.

In economic terms, the mentioned increase in production and marketing was also influenced by technological modernization and economic shifts reinforced by the Plano Real (Real Plan, a set of measures taken to stabilize the Brazilian economy in 1994). Such factors contributed to the decrease in production costs and, consequently, to a better organization of the entire milk production chain, which generated better financial results.

The behavior of prices and their evolution beyond the farm gate can be explained by the following factors: supply and demand; industry and producer; changes in the milk market; and government interference in livestock (Vilela et al., 2017). 
DOI: 10.14807/ijmp.v12i4.1309

Dairy activity in Brazil is full of challenges, which are concentrated on pricing policies, production methods and technology and product logistics. Therefore, it is necessary to integrate the entire production chain in order to meet the central objectives of dairy farming. Involving all actors in the chain is of paramount importance, so that the Brazilian milk production continues to consolidate itself as an important sector of agribusiness.

\subsection{Milk Agribusiness In The States Of Minas Gerais And Paraná}

The milk production chain, which is named by Assmann et al. (2016) as the "AgroFood System” (AFS) for milk, is a set of diverse practices which involves organizations that, in a way, keep everything interconnected for the development of activities in the dairy segment (Assman et al., 2016). The same authors state that analyzing the milk production chain is a very complex activity, since milk production involves several actors in a network that needs a lot of dialogue among its members.

Figure 2 shows the Brazilian states with the largest milk production in the country. It can be noted that Minas Gerais and Paraná stand out as important producers (Perobelli, Araújo Júnior \& Castro, 2018). In the case of Paraná, in 2015, there was a considerable improvement in its position, which guaranteed the second place to the state, surpassing important players like Rio Grande do Sul and São Paulo (Perobelli, Araújo Júnior \& Castro, 2018). For a better understanding of the statistics of milk production, figure 2 presents information about the states participating in the milk production chain.

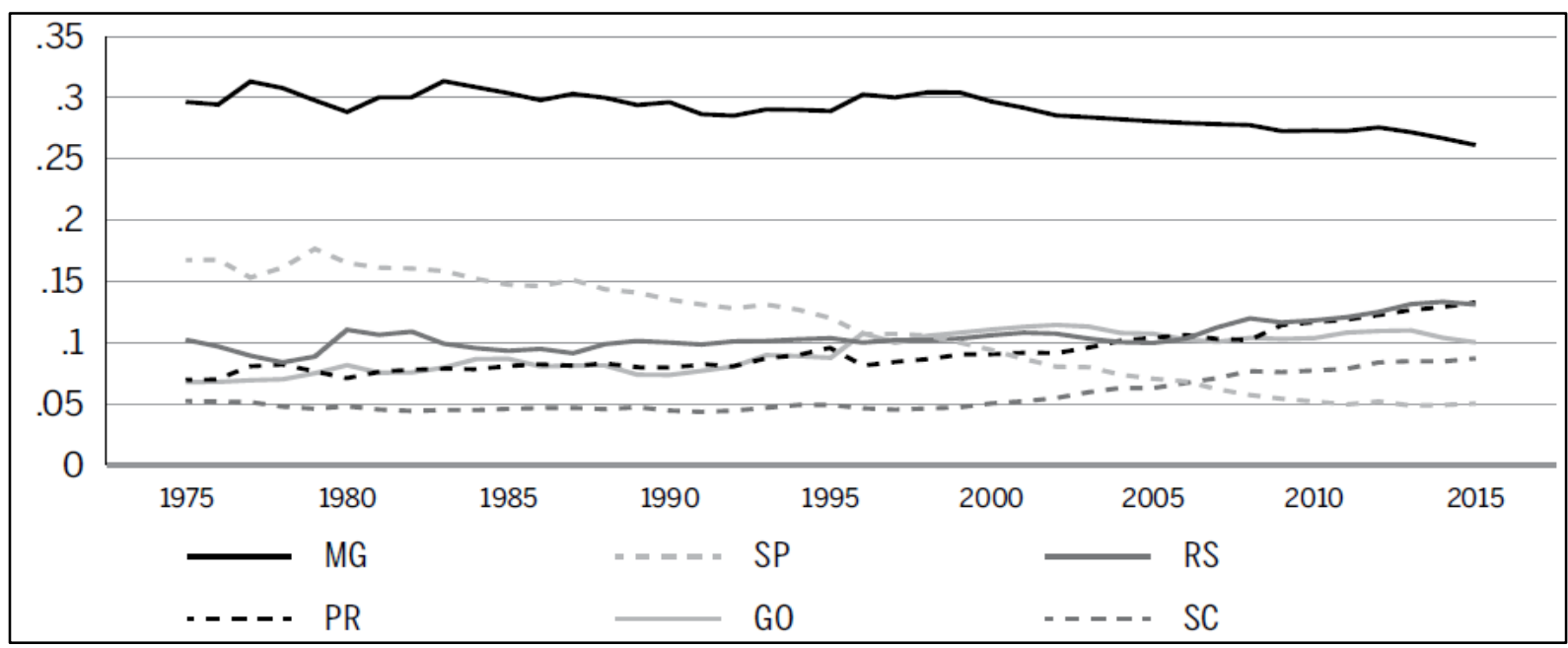

Figure 2: Milk production in the most important Brazilian states.

Source: Available in (Perobelli, Araújo Júnior \& Castro, 2018, p. 302).

Caption: MG - Minas Gerais; SP - São Paulo; RS - Rio Grande do Sul; PR - Paraná; GO - Goiás; SC - Santa Catarina.

Minas Gerais stands out due to recent production changes. Dairy farmers differentiate their production practices by approaching technologies. Moreover, the state has also been 
INDEPENDENT JOURNAL OF MANAGEMENT \& PRODUCTION (IJM\&P)

http://www.ijmp.jor.br

v. 12, n. 4, May-June 2021

ISSN: 2236-269X

DOI: 10.14807/ijmp.v12i4.1309

engaging in other types of agricultural production, which guarantees an opportunity for producers for the good use of their land for cattle breeding.

Differences in regional production in the state of Minas Gerais may occur due to the formulations of regional production chains already exemplified in figure 1 (production chain). The formulation and practices of actors in the regional chain interfere in the production of each region of the state.

The milk production in Minas Gerais is formed by small and medium-sized dairy products (Perobelli, Araújo Júnior \& Castro, 2018). The good results of milk production are related to the infrastructure and to the network growth of the production of the municipalities that take part in the dairy culture - that is, the organization of the chain and the network among the municipalities ensures that the milk production in Minas Gerais continues to stand out in relation to the national dairy production.

The milk production chain in Paraná has a hybrid governance structure, as it involves formal and informal contracts between producers and processors. The two profiles of specialized and non-specialized producers are also found (Acosta \& Souza, 2017). Over time, the state has seen its milk production grow very significantly. Between 1997 and 2006, Paraná's milk production increased by $71 \%$, which consolidated the state as the second largest dairy producer in the country (Ipardes, 2009). Dairy production technology has gradually contributed to the consolidation of dairy farming in the state of Paraná (Silva, Camara \& Telles, 2016).

Milk production in Paraná was organized based on three structures: technology, governance and legislation. The changes in milk production did not develop in a straight line in the country and in Paraná, since there are several factors that interfere, such as climate, geographic and cultural aspects, economic development, among others. Such factors interfere in the diversity of the dairy field and its structure as a production chain (Acosta \& Souza,2017).

In the milk production of Paraná, the discussion of the Differentiated Agrifood System (DAS) is also highlighted in an incipient way. In the DAS, the production method adopted is the agroecological one, which is mainly characterized by the production of organic milk, a differentiated product due to a production system that refuses the use of pesticides and takes care of the well-being of the animal (Nogueira et al., 2018).

The profile of the dairy farmer in Paraná is characterized as a family farmer who perceives dairy farming as the main source of income, in addition to the social security pension or retirement benefits (Bazotti, Nazareno \& Sugamosto, 2012). Generally, the properties of milk producers are formed by an average three-member family. The labor force is usually female, but men take charge of the management of milk production. Paraná producers sell their 
DOI: 10.14807/ijmp.v12i4.1309

production to buyers, who, generally, are small and medium-sized processors, cooperatives, large industries and large food industries (Acosta \& Souza, 2017).

Financing policies are not used by dairy farmers, as they do not believe they will be able to pay the financing and risk losing their land afterwards. Cooperatives and associations develop important work to represent dairy farmers (Ipardes, 2009).

It is shown that the fixed cost of production in Paraná is high, in the research that compares milk production in Paraná and in the Province of Santa Fé, in Argentina, which ends up making production values more expensive and, consequently, makes the producers have lower profit rates with their production (Hofer \& Shikida, 2000).

\section{METHODOLOGY}

This research adopted the quantitative research method, which is used in the development of researches in the social, communication, marketing, administrative and economic fields, generally representing a guarantee of the accuracy of the results, avoiding mistakes and distortions in the interpretation of the data (Oliveira, 2002).

For a comparison between the milk production chains of Minas Gerais and Paraná, data were collected in all the municipalities of these two states - 853 in Minas Gerais and 394 in Paraná. Such data were obtained from the Instituto Brasileiro de Geografia e Estatística (IBGE) (Brazilian Institute of Geography and Statistics), considering the period from 2008 to 2017. The variables analyzed were: milk production, number of dairy cows, productivity and production value of each municipality/state. The secondary data obtained were tabulated and processed using the Statistical Package for the Social Sciences (SPSS) software. For data analysis, the following statistical techniques were used: analysis of variance (ANOVA), analysis of clusters, adoption of the Ward agglomerative method and discriminant analysis.

ANOVA was used to compare the averages of the variables. Hypotheses were tested the null hypothesis is that all averages are equal (Malhotra, 2006). For the comparison of averages using ANOVA, the distribution of variables must have a normal distribution (Maroco, 2007). This technique can be used depending on the research carried out. When the intention is to compare a dependent variable with more than two dependent groups, we use ANOVAone-way. If there is more than one factor, the analysis of variances must be done by the factorial ANOVA (Maroco, 2007). In this article, we used ANOVA-one-way, since the comparison was made between two variables. As it was already mentioned, a comparison of the averages of the variables milk production, dairy cows, productivity and production value between Minas Gerais and Paraná, in the period from 2008 to 2017, was carried out. 
DOI: 10.14807/ijmp.v12i4.1309

Cluster analysis was used to group the observations according to their similarity.

The analysis of groups or clusters is an exploratory technique of multivariate analysis that allows to group subjects or variables in homogeneous groups in relation to one or more common characteristics. Each observation belonging to a specific cluster is similar to all others belonging to that cluster and is different from the observations belonging to the other clusters (Maroco, 2007, p. 421).

The cluster analysis is important the purpose of grouping observations of similar characteristics (Hair Júnior et al., 2005, p. 193; Maroco, 2007, p. 421) and

The resulting clusters of objects must then exhibit high internal homogeneity (within clusters) and high external heterogeneity (between clusters). Thus, if the classification is successful, the objects within the groupings will be close when represented graphically and different groupings will be distant. (Hair Júnior et al., 2005, p. 384).

The use of cluster analysis in this work was based on the grouping of observations regarding the productivity variable. The number of four clusters was defined in the following way: group 1 refers to very low productivity; group 2, low productivity; group 3, medium productivity; and group 4, high productivity. The option for this variable for the construction of clusters was considered as an important indicator of the efficiency in the milk production chain.

The discriminant analysis was used to assess which variables discriminated and which had the greatest influence on the four groups formed in the cluster analysis of each state. Hair Júnior et al. (2005) state that the discriminant analysis involves determining a statistical variable. A discriminating statistical variable is the linear combination of the two (or more) independent variables that are best discriminated among objects (people, companies etc.) in the groups defined a priori. The discrimination establishes the weights of the statistical variable so that each independent variable maximizes the differences among the groups. The statistical variable for discriminating analysis, also known as the "discriminating function", is determined by an equation.

\section{ANALYSIS OF RESULTS AND DISCUSSIONS}

Tables 1 and 2 show the values of the averages of the variables milk production, dairy cows, productivity and production value of the states considered in this research. As we can see, milk production in Minas Gerais increased from 2008 to 2014, but there was a decrease of 2.41\% in 2015 as compared to 2014. This decrease was caused by climatic problems and by the increase in production costs (Seab, 2017). Despite such numbers, the state remains the top 


\section{INDEPENDENT JOURNAL OF MANAGEMENT \& PRODUCTION (IJM\&P)}

http://www.ijmp.jor.br

v. 12, n. 4, May-June 2021

ISSN: 2236-269X

DOI: 10.14807/ijmp.v12i4.1309

producer in the country. The state of Paraná showed an increase in its production from 2008 to 2016, jumping to the second place in the national ranking of milk producing states.

As milk production dropped, the same could be seen in the number of dairy cows, which fell by $7.10 \%$ in Minas Gerais and 5.19\% in Paraná, due to the factors previously mentioned. Regarding the value of production, we observed a slight decrease (1.8\%) in 2015 compared to 2014 in Minas Gerais - followed by an increase in 2016 (18.41\%). In the analysis, it was observed that even with the decrease in production and in the number of dairy cows, the value of production continued to grow in Paraná and Minas Gerais (with the exception of 2015), which can be explained by the productivity factor. Productivity increased $67.76 \%$ in Minas Gerais and 45.58\% in Paraná, in the years from 2008 to 2017, which means that, even with a reduced production, there may have been a reduction in property costs, since there was a reduction in the number of milked animals.

Table 1: Average numbers of the variables milk production, dairy cows, productivity and production value in the municipalities of Minas Gerais.

\begin{tabular}{ccccc}
\hline Year / variable & Milk production & Dairy cows & Productivity & Production value \\
\hline 2008 & 8976.93 & 6030.12 & 1408.12 & 5934.40 \\
2009 & 9297.93 & 6188.48 & 1412.35 & 6237.64 \\
2010 & 9833.58 & 6385.70 & 1439.12 & 7059.49 \\
2011 & 10265.07 & 6601.49 & 1451.38 & 8132.85 \\
2012 & 10440.78 & 6652.16 & 1462.30 & 8768.83 \\
2013 & 10913.43 & 6859.01 & 1486.92 & 10821.54 \\
2014 & 10985.32 & 6809.52 & 1507.93 & 10901.47 \\
2015 & 10720.95 & 6358.35 & 1580.24 & 10708.74 \\
2016 & 10516.74 & 5831.71 & 1704.88 & 12680.05 \\
2017 & 10448.50 & 3990.12 & 2362.29 & 11161.31 \\
\hline
\end{tabular}

Milk production (1000 liters / state / year); Dairy cows (heads / state / year); Productivity (liters / cow / state / year); Production value (R\$1000 / state / year).

Source: Research data (2019).

Table 2: Average numbers of the variables milk production, dairy cows, productivity and production value in the municipalities of Paraná.

\begin{tabular}{ccccc}
\hline Year / variable & Milk production & Dairy cows & Productivity & Production value \\
\hline 2008 & 7114.12 & 3349.18 & 17178 & 4002.95 \\
2009 & 8384.18 & 3741.40 & 1843.54 & 5035.58 \\
2010 & 9012.04 & 3895.24 & 1945.52 & 5965.91 \\
2011 & 9569.90 & 3994.22 & 1997.64 & 7175.92 \\
2012 & 9948.19 & 4059.45 & 2062.55 & 8056.34 \\
2013 & 10907.95 & 4311.53 & 2093.01 & 9907.89 \\
2014 & 11380.86 & 4335.35 & 2185.63 & 10655.69 \\
2015 & 11683.74 & 4121.62 & 2323.77 & 11334.23 \\
2016 & 11841.92 & 4050.92 & 2413.25 & 14626.77 \\
2017 & 11120.37 & 3624.39 & 2550.27 & 12794.40
\end{tabular}

Milk production (1000 liters / state / year); Dairy cows (heads / state / year); Productivity (liters / cow / state / year); Production value (R\$ 1000 / state / year).

Source: Research data (2019). 
DOI: 10.14807/ijmp.v12i4.1309

The analysis of the variance in milk production, production value, dairy cows and productivity is shown in table 3. As it can be seen, in the ANOVA of milk production, there was a 5\% significance only in 2008. In the other years, there was no significance. Therefore, Minas Gerais presented a superior milk production in comparison with Paraná in every year considered; however, statistically there was no significant difference in milk production from 2009 to 2017.

Table 3: ANOVA for the variables milk production, dairy cows, productivity and production value in the municipalities of Paraná and Minas Gerais.

\begin{tabular}{c|cc|cc|ccc|cc}
\hline \multirow{2}{*}{$\begin{array}{c}\text { Year } / \\
\text { Variable }\end{array}$} & \multicolumn{2}{c}{ Milk production } & \multicolumn{2}{c}{ Dairy cows } & \multicolumn{2}{c}{ Productivity } & \multicolumn{2}{c}{ Production value } \\
\cline { 2 - 7 } & F & Sig. & F & Sig. & F & Sig. & F & Sig. \\
\hline 2008 & 5.649 & 0.018 & 45.025 & 0.000 & 61.716 & 0.000 & 14.666 & 0.000 \\
2009 & 1.144 & 0.285 & 34.910 & 0.000 & 85.985 & 0.000 & 4.621 & 0.032 \\
2010 & 0.841 & 0.359 & 33.770 & 0.000 & 110.023 & 0.000 & 2.909 & 0.088 \\
2011 & 0.526 & 0.468 & 34.945 & 0.000 & 125.495 & 0.000 & 1.612 & 0.204 \\
2012 & 0.242 & 0.623 & 32.180 & 0.000 & 149.967 & 0.000 & 0.679 & 0.410 \\
2013 & 0.000 & 0.996 & 28.724 & 0.000 & 151.947 & 0.000 & 0.736 & 0.391 \\
2014 & 0.134 & 0.714 & 27.159 & 0.000 & 185.638 & 0.000 & 0.056 & 0.814 \\
2015 & 0.774 & 0.379 & 23.823 & 0.000 & 196.750 & 0.000 & 0.322 & 0.571 \\
2016 & 1.507 & 0.220 & 18.247 & 0.000 & 161.403 & 0.000 & 1.863 & 0.173 \\
2017 & 0.379 & 0.538 & 1.453 & 0.228 & 7.937 & 0.005 & 1.720 & 0.190 \\
\hline \multicolumn{3}{c}{ Source: Research data (2019) }
\end{tabular}

Regarding the value of production, the behavior of milk production was similar. It was tested and found that the difference in the averages between Minas Gerais and Paraná was highly significant (1\%) only in 2008. The number of dairy cows was highly significant in the years from 2008 to 2016. In 2017, there were no significant differences between the averages, because there was a decrease of 31.6\% in the number of dairy cows in Minas Gerais and, in Paraná, a decrease of only $10.5 \%$ - therefore, the averages stood close. Lastly, in terms of productivity, it was highly significant from 2008 to 2016 and significant in 2017, when Paraná presented better milk productivity averages compared to Minas Gerais (table 1).

The cluster analysis was also carried out in order to group the municipalities according to their productivity. In order to do so this, the total productivity of cows in liters per municipality was calculated for the analyzed period (years from 2008 to 2017) for each state.

Based on the cluster analysis, four groups were defined for each state: 1) very low productivity; 2) low productivity; 3) medium productivity; and 4) high productivity. Analyzing table 4, it can be noted that in Minas Gerais the group with the highest frequency was of medium productivity (with 33.1\%), and that the group with the lowest frequency was the one with high productivity (with 10.2\%). In Paraná, the group with the highest frequency was the one with very low productivity, with $54.6 \%$, and the one with the lowest frequency was the highest productivity, with $6.1 \%$. 
INDEPENDENT JOURNAL OF MANAGEMENT \& PRODUCTION (IJM\&P)

http://www.ijmp.jor.br

v. 12, n. 4, May-June 2021

ISSN: 2236-269X

DOI: 10.14807/ijmp.v12i4.1309

The results of the cluster analysis indicated that, for the state of Paraná, below 19643.9 liters/cow/year would be the limit for the municipality with productivity to be considered to have very low productivity. On the other hand, in Minas Gerais, this item was much lower in relation to Paraná - that is, with 11505.5 liters/cow/year so that the municipality could be considered to be of low productivity. For a comparison, the value of 19643.9 liters/cow/year, which is considered the limit to be within the group of municipalities with very low productivity in Paraná, would be considered a municipality of medium productivity in Minas Gerais, a group that presents an interval productivity from 16659.85 to 23468.72 liters/cow/year.

Table 4: Result of the cluster analysis of the municipalities of Minas Gerais (MG) and Paraná (PR), with their frequencies, minimum and maximum productivity limits for each group.

\begin{tabular}{ccccccc}
\hline Groups & $\begin{array}{c}\text { Frequency } \\
\text { MG }\end{array}$ & Frequency PR & $\begin{array}{c}\text { Minimum } \\
\text { MG }\end{array}$ & $\begin{array}{c}\text { Maximum } \\
\text { MG }\end{array}$ & $\begin{array}{c}\text { Minimum } \\
\text { PR }\end{array}$ & $\begin{array}{c}\text { Maximum } \\
\text { PR }\end{array}$ \\
\hline Very low & 208 & 215 & 4129.42 & 11505.50 & 5961.85 & 19643.90 \\
Low & 276 & 90 & 11632.96 & 16578.11 & 19836.51 & 28544.60 \\
Medium & 282 & 65 & 16659.85 & 23468.72 & 28923.81 & 27601.4 \\
High & 87 & 24 & 23707.4 & 49769.5 & 38517.95 & 73245.2 \\
Total & 853 & 394 & - & - & - & - \\
\hline
\end{tabular}

Frequency: number of municipalities belonging to each group by state; Minimum: Minimum required productivity in liters of cows / municipality / period determined by cluster analysis by group; Maximum: Maximum required productivity in liters of cows / municipality / period determined by cluster analysis by group.

Source: Research data (2019).

Considering both states, the municipality with the lowest productivity is Divisa Alegre, which belongs to the state of Minas Gerais, with a productivity of 4129.42 liters/cow/year such number corresponds to $1.13 \mathrm{l}$ cow per day. On the other extreme, we have the municipality of Castro, in the state of Paraná, which presented the best productivity of the two states: 73245.2 liters cow/year, the same as 20.07l cow per day. The municipality of Castro stands out in terms of milk production and productivity in Brazil. It was even awarded the title of “Brazilian Capital of the Milk” by Law number 13.584, in force since December $26^{\text {th }} 2017$ (Brasil, 2017).

Due to the fact that Paraná has higher productivity indexes in relation to Minas Gerais, its limits are better in relation to Minas Gerais in the analyzed aspects (very low, low, medium and high productivity). It was found that some municipalities that are considered to have high productivity in Minas Gerais do not enter this same group in Paraná.

For the discriminant analysis, the four groups extracted by the cluster analysis were defined as the dependent variable. Tables 5 and 6 show the independent variables, all considered highly significant $(0.000)$ by the discriminant analysis. 
INDEPENDENT JOURNAL OF MANAGEMENT \& PRODUCTION (IJM\&P)

http://www.ijmp.jor.br

v. 12, n. 4, May-June 2021

ISSN: 2236-269X

DOI: 10.14807/ijmp.v12i4.1309

Table 5: Results of the discriminant analysis of the groups in Paraná with the extraction stages, Wilks' Lambda statistics and level of significance for each variable.

\begin{tabular}{cccc}
\hline Stage & Inserted & Wilk's Lambda & Sig. \\
\hline 1 & Total production PR & 0.623 & 0.000 \\
2 & Total dairy cows PR & 0.581 & 0.000 \\
3 & Total production value PR & 0.521 & 0,000 \\
\hline
\end{tabular}

Source: Research data (2019).

In Paraná, according to the data presented in table 5, it seems that the variable value of total production was the first to enter the discriminant function, which means that this variable was the one that most discriminated the four groups regarding productivity. The variable "dairy cows" was the second to enter the model, followed by total production.

Table 6 shows the three discriminating variables of the four groups in Minas Gerais. The variable "total production" was the first to enter the model, followed by the variables "total dairy cows" and "total production value".

Table 6: Results of the discriminant analysis of the groups in Minas Gerais with the extraction stages, Wilks' Lambda statistics and level of significance for each variable.

\begin{tabular}{cccc}
\hline Stage & Inserted & Wilk's Lambda & Sig. \\
\hline 1 & Total production value MG & 0.806 & 0.000 \\
2 & Total dairy cows MG & 0.602 & 0.000 \\
3 & Total production MG & 0.560 & 0.000 \\
\hline
\end{tabular}

As previously mentioned, the results demonstrate that there is a marked difference between the two states. Minas Gerais has the highest total milk production and, on the other hand, Paraná has the best productivity. According to the Censo Agropecuário (Brazilian Agriculture Census) conducted by the IBGE, between 2006 and 2017 the number of establishments that produced milk fell by $2.98 \%$ in Minas Gerais and by $27.34 \%$ in Paraná. However, the same did not happen with milk production (as shown in table 7). This be attributable to technological advances (Perobelli, Araújo Junior \& Castro, 2018): even with the expressive decrease in the number of rural producers in Paraná, milk production suffered no impact.

Table 7: Number of establishments that produced milk in Minas Gerais and Paraná.

\begin{tabular}{cccc}
\hline \multirow{2}{*}{ Year } & \multicolumn{2}{c}{ State } \\
\cline { 2 - 3 } & 2017 & Minas Gerais & Paraná \\
\hline 2006 & 216.419 & 87.048 \\
& 223.073 & 119.810 \\
\hline
\end{tabular}

Source: Censo Agropecuário (IBGE, 2006; 2017).

It can be said that Paraná has shown to be more efficient in the milk production chain compared to Minas Gerais in the analyzed period. Unlike Minas Gerais, in Paraná the variable that most discriminated against the four groups was production because it had higher productivity. Minas Gerais has the top milk production in Brazil and has a higher number of municipalities than Paraná - therefore, the value of milk production had greater divergence 
INDEPENDENT JOURNAL OF MANAGEMENT \& PRODUCTION (IJM\&P)

http://www.ijmp.jor.br

v. 12, n. 4, May-June 2021

ISSN: 2236-269X

DOI: 10.14807/ijmp.v12i4.1309

between the groups of Minas Gerais for presenting a smaller interval of milk production as compared to Paraná.

In Minas Gerais, milk production dropped slightly in 2017 (table 1), after an increase of nine consecutive years. This was due to increased productivity. With the increase in productivity, even with fewer establishments, production continued to increase. Productivity is an index that indicates the efficiency of a milk producing establishment. Therefore, it was found that Paraná is superior in productivity in relation to Minas Gerais in the analyzed period. The adoption of technologies, animals of proven genetic quality, good management practices and technical assistance to rural producers may have influenced Paraná’s high productivity.

In 2017, of the total milk producing properties in Minas Gerais (216.419 properties), $70.27 \%$ of them did not receive any type of technical assistance, number which corresponds to 152.079 rural properties without access to external technical information (IBGE, 2017). In Paraná, of the total number of properties (87.048 establishments), 47.83\% did not receive technical assistance. The fact that the rural producer in Minas Gerais did not modernize, improve techniques, improve livestock, among other practices, may have contributed to the significant difference in the technical efficiency of the production (IBGE, 2017).

\section{CONCLUSIONS}

The objective of this study was to evaluate the differences and similarities of the milk production chain in the Brazilian states of Minas Gerais and Paraná in the years from 2008 to 2017. In order to do so, variables related to dairy activity were analyzed for the 853 municipalities in Minas Gerais and for the 394 municipalities in Paraná, according to data released by the IBGE.

The differences in averages of these variables between the two states were tested using ANOVA, which presented expressive results regarding the differences in the production chain of these two states. The cluster analysis was also carried out for each state - that is, the municipalities were grouped considering the productivity variable. In Paraná, the productivity limits among the extracted clusters proved to be higher and therefore more rigorous.

The results of the discriminant analysis showed the main differences between the states, considering the clusters as a dependent variable. The significant independent variables for the two states were extracted. In Paraná, the variables in order of extraction were: total production, total dairy cows and total production value. On the other hand, in Minas Gerais, the variables in order of extraction were: value of total production, total dairy cows and total production. 
DOI: 10.14807/ijmp.v12i4.1309

Membership in cooperatives can be an alternative for rural producers to improve zootechnical production rates, in addition to having efficient technical assistance on their property. The municipality of Castro, belonging to the state of Paraná, was the one that stood out the most in this work, performance for which the Castrolanda Cooperative is mainly responsible. Nowadays, this cooperative has 877 members and is one of the most well-known cooperatives in the country, having already received recognition and awards, such as "The farm of the year”, for its national prominence in dairy farming (CASTROLANDA, 2019). This cooperative may have influenced directly in the recognition of the municipality of Castro as the Brazilian Capital of Milk.

The results point to the importance of adopting technology in the milk production chain. This factor was reflected in this work indirectly in the productivity variable, improving production. To become more competitive in the market, dairy farms must invest in technology, genetics and technical assistance.

The state of Minas Gerais presented higher values of the variables milk production, dairy cows and production value in relation to the state of Paraná, but it was lower in the productivity variable. Productivity is the factor that demonstrates the efficiency of the dairy activity. If there is investment in technology, genetics and technical assistance, there will be a tendency to increase productivity rates.

The limitations of this work are related to the method of data collection and secondary measures, as well as in relation to the exclusion of the year 2018. The lack of some variables was also a limiting factor, such as the average production cost of dairy farms and the number of producers for each year analyzed in the study, since these data would be useful for an indepth investigation and comparison between these two states.

As a result of the discussions in this work, it is possible to suggest a research agenda in relation to the milk production chain in Brazil. Therefore, it is suggested that the following studies be carried out: a) a research involving comparisons among the production chains of other states and others regions of the country, so that we can have a broader understanding of how milk production chains in Brazil develop and function; b) an analysis of the specific patterns of dairy production in Brazil and how they impact in the production processes; c) a development of specific research in the North and Northeast regions on the milk production of the states of such regions, in order to understand why their milk production is lower in relation to the states in other regions of the country; and d) a comparison between the Brazilian production chain and those of other countries that are reference in production and productivity, 
DOI: 10.14807/ijmp.v12i4.1309

in order to identify positive aspects and aspects that can be improved in the national milk production chain.

\section{REFERENCES}

Acosta, D. C., \& Souza, J. P. (2017). Estratégias de organização da cadeia do leite no Paraná. Revista Ibero-Americana de Estratégia - RIAE, 16(2), 68-89. Available: http://www.spell.org.br/documentos/ver/45796/estrategias-de-organizacao-da-cadeia-doleite-no-parana/i/pt-br. Access: 11/11/2018. DOI: 10.5585/riae.v16i2.2451.

Assmann, D. M., Sparemberg, A., Zamberlan, L., \& Büttenbender, P. L. (2016). Agronegócio e a cadeia produtiva do leite: Desafios e Comportamento dos produtores rurais. In: Congresso Virtual De Administração - CONVIBRA. Available:

http://www.convibra.com.br/upload/paper/2016/30/2016_30_12986.pdf. Access: 20/09/2018.

Bacha, C. J. C. (2004). Economia e política agrícola no Brasil, São Paulo: Atlas.

Bazotti, A., Nazareno, L. R., \& Sugamosto, M. (2012). Caracterização Socioeconômica e Técnica da Atividade Leiteira do Paraná. Revista Paranaense de Desenvolvimento, 123, 213-234. Available:

http://www.ipardes.gov.br/ojs/index.php/revistaparanaense/article/view/73/762. Access: 15/11/2019.

Brasil (2017). Lei $\mathbf{n}^{\mathbf{0}}$ 13.584, 26 de dezembro de 2017. Available: https://www2.camara.leg.br/legin/fed/lei/2017/lei-13584-26-dezembro-2017-786021publicacaooriginal-154640-pl.html. Access: 08/01/2019.

Brum, A. L., Kelm, M., Albornoz, M., \& Avila, D. F. (2014). Semelhanças e diferenças: uma análise entre as cadeias produtivas do leite no estado do Rio grande do Sul (Brasil). e na província de Buenos Aires (Argentina).. In: I Mostra de Estudos do Desenvolvimento: Linha de Pesquisa Desenvolvimento Territorial e Gestão de Sistemas Produtivos, IjuíRS, 2014.

Castrolanda (2019). Prêmios e Reconhecimento. Castro-PR.Available: https://www.castrolanda.coop.br/reconhecimento. Access: 18/08/2019.

Censo Agropecuário (2017). Sistema IBGE de Recuperação Automática -SIDRA. Brasília. Food and Agriculture Organization of the United Nations (FAO). (2009). How to Feed the World in 2050, Food and Agriculture Organization, Rome, Italy, Available: http://www.fao.org/fileadmin/templates/wsfs/docs/expert_paper/How_to_Feed_the_World_in _2050.pdf. Access: 04/11/2019.

Hair Jr, J. F., Anderson, R. E., Tatham, R. L., \& Black, W. C. (2005). Análise Multivariada de Dados, 5 ed. Porto Alegre: Bookman.

Hofer, E., \& Shikida, P. F. A. (2000). Estudo do custo de produção do leite na Província de Santa Fé (Argentina). e no Estado do Paraná (Brasil). Revista Paranaense de

Desenvolvimento, Curitiba, 98, 99-107. Available:

http://www.ipardes.gov.br/ojs/index.php/revistaparanaense/article/view/255/211. Access: 25/07/2019.

Instituto Paranaense de Desenvolvimento Econômico e Social (IPARDES)., Instituto Paranaense de Assistência Técnica e Extensão Rural (2009). Caracterização socioeconômica da atividade leiteira no Paraná: sumário executivo. Curitiba. Available: 
INDEPENDENT JOURNAL OF MANAGEMENT \& PRODUCTION (IJM\&P)

http://www.ijmp.jor.br

v. 12, n. 4, May-June 2021

ISSN: 2236-269X

DOI: 10.14807/ijmp.v12i4.1309

http://www.ipardes.gov.br/biblioteca/docs/sumario_executivo_atividade_leiteira_parana.pdf. Access: 18/06/2019.

Leme, P. H. (2011). Marketing no agronegócio: estratégia e comprometimento para o futuro. In: RDI - Rede de Desenvolvimento Integrado. Fundação Dom Cabral. Belo Horizonte.

Lopes Jr, J. F., Ramos, C. E. C. O., Santos, G. T., Grande, P. A., Damasceno, J. C., \& Massuda, E. M. (2012). Análise das práticas de produtores em sistemas de produção leiteiros e seus resultados na produção e qualidade do leite. Semina: Ciências Agrárias, Londrina, 33(3), 1199-1208. Available:

http://srv009.uel.br/seer/index.php/semagrarias/article/view/8848/10856. Access: 15/08/2019. DOI: 10.5433/1679-0359.2012v33n3p1199.

Malhotra, N. K. (2006). Pesquisa de marketing: uma orientação aplicada, Porto Alegre: Bookman.

Maroco, J. (2007). Análise estatística com utilização do SPSS, Lisboa: Edições Silabo.

Moraes, B. M. M., \& Bender Filho, R. (2017). Mercado Brasileiro de Lácteos: análise do impacto de políticas de estímulo à produção. RESR, 55(4), 783-800. Available:

http://www.scielo.br/pdf/resr/v55n4/1806-9479-resr-55-04-783.pdf. Access: 19/09/2019.

Nogueira, C. R., Bánkuti, S. M. S., Lourenzani, A. E. B. S., Bánkuti, F. I., \& Lourenzani, W. L. (2018). Coordenação de sistemas agroalimentares diferenciados: um estudo sobre o leite orgânico no Paraná. Gestão \& Regionalidade, 34(100), 74-91. Available:

https://seer.uscs.edu.br/index.php/revista_gestao/article/view/3696/2367. Access: 12/06/2019. DOI: $10.13037 /$ gr.vol.34n100.3696.

Oliveira, S. L. (2002). Tratado de metodologia científica. São Paulo: Pioneira.

Perobelli, F. S., Araújo Jr, I. F., \& Castro, L. S. (2018). As dimensões espaciais da cadeia produtiva do leite em Minas Gerais. Nova Economia, 28(1), 297-337. Available:

http://www.scielo.br/pdf/neco/v28n1/0103-6351-neco-28-01-297.pdf. Access: 13/03/2019.

DOI: https://doi.org/10.1590/0103-6351/4789.

Secretaria de Estado da Agricultura e do Abastecimento (SEAB)., Departamento de Economia Rural - Deral Leite (2018). Análise da Conjuntura Agropecuária Ano 2016/17. Curitiba. Available:

http://www.agricultura.pr.gov.br/arquivos/File/deral/Prognosticos/2017/leite_. Access: 15/07/2019.

Silva, L. H., Camara, M. R. G., \& Telles, T. S. (2016). Evolução e distribuição espacial da produção de leite no estado do Paraná, Brasil. Acta Scientiarum. Human and Social Sciences, Maringá, 38(1), 37-47. Available:

http://periodicos.uem.br/ojs/index.php/ActaSciHumanSocSci/article/view/30006/pdf. Access: 16/072019. DOI: https://doi.org/10.4025/actascihumansoc.v38i1.30006.

Slomp, M. N. (2003). Cadeia agroindustrial do leite: as mudanças no ambiente competitivo e as novas demandas para o segmento da produção. Dissertation (Master in Economic)..

Florianopólis-SC, UFSC. Available:

http://repositorio.ufsc.br/xmlui/handle/123456789/85552. Access: 04/08/2018.

Vilela, D., Resende, J. C., Leite, J. B., \& Alves, E. (2017). A evolução do leite no Brasil em cinco décadas. Revista de Política Agrícola, 1, 5-24. Available:

https://ainfo.cnptia.embrapa.br/digital/bitstream/item/163208/1/Evolucao-do-leite-nobrasil.pdf. Access: 15/04/2019. 